\title{
Global education and cross-cultural learning: A challenge for a research- based approach to international teacher education ${ }^{1}$
}

\author{
Annette Scheunpflug
}

Friedrich-Alexander-University of Erlangen-Nuremberg (Germany)

\begin{abstract}
This article discusses teaching competencies for global education, beginning with an outline of some of the challenges for orientation and learning which are the result of rapid globalisation. An example of a situation in a recent class is used to illustrate the kinds of professional challenges that teachers encounter, including those related to dealing with paternalism, complexity and insecurity. The consequences of these challenges for teacher education are then outlined. Finally, the discussion highlights a number of areas of research which are needed in the future and suggest a framework for research-based teacher education in global learning.
\end{abstract}

Keywords: Global learning, teacher education, teacher education research

\section{Introduction: A Micro-Level Example}

Let me take you into a situation I experienced in a third grade classroom some years ago. It was Monday morning and every student had the opportunity to tell what he or she had done over the weekend. One pupil reported that he had read a book about a famous European mountain climber, Reinhold Messner, who climbs mountains like Mount Everest without oxygen-support and writes books about his adventures. Like many young boys, the boy telling about the book saw Messner as a personal hero and knew a lot about the details of his climbing and of the landscape of Nepal. He finished by saying: 'Messner climbed in a region where, he said, for two generations, no people from Europe had ever been seen'. After listening to some of the other students, the teacher told her own weekend story about visiting her parents in lower Bavaria. She ended by saying: 'And they live in a desolate region where, for the past 17 generations, no Nepalese people have ever been seen'. An intensive discussion immediately ensued in the classroom, characterised by humour and surprise, and to which the pupil who reported about Messner actively contributed. The teacher's deliberate change of perspective had opened her students' minds to the concept of paternalism and its critique. 
With that one sentence, the teacher had initiated an opportunity for her students to engage in global learning. She also demonstrated several important professional competencies:

- knowing her students well enough to judge whether an intervention like this would stimulate or confuse them, and

taking advantage of a fruitful, teachable moment.

Moreover, in addition to these general professional competencies, the teacher demonstrated other competencies which are specifically related to global learning and global issues:

- she was sensitive towards her students' tendency to take Europeans' superiority in the world for granted,

- she had a sense of how to get students to look through other lenses and perspectives, and

- she was able to activate her students' own reconceptualisation of these issues.

This example highlights how the complexity of globalisation, and the competencies a teacher needs for global education and cross-cultural learning, can be conceptualised on the micro-level. To address these issues further, I will first outline some dimensions of globalisation and its consequences for learning, then review relevant research on teacher competencies, and finally suggest a framework for researchbased teacher education in global learning.

\section{Globalisation as a Challenge for Teaching}

Globalisation affects teachers along many dimensions and in numerous ways. Although there is no single definition for the term 'globalisation' (cf. Scheuermann, 2006; for a political perspective see Beck, 1999; Robertson, 1992 and 1995; for a sociological perspective see Blossfeld and Mills, 2005; for an economic perspective see Stieglitz, 2002; Prestowitz, 2005 and Dieter 2005; for a system level educational context see VBW, 2008 and Scheunpflug, 2003), some aspects of globalisation, and especially those concerning perceptions of society, are common to the majority of theories. On the one hand, society is seen in a national or even local context, while on the other hand it is viewed as part of the wider world context. Following Luhmann's theoretical perspective (see Luhmann, 1975; 1982; 1992 and 1995; Stichweh, 1995 and 1996; Albert and Hilkermeier, 2004), I propose that the following are key features of globalisation:

\section{Globalisation is plural, not singular}

Globalisation does not have a single face, but a plurality of aspects, depending upon where and how one lives. The universal process of globalisation shapes national patterns in different ways (Sen, 1999; Blossfeldt et al., 2008). States develop specific

30 International Journal of Development Education and Global Learning 3(3) 2011 
ways of filtering globalisation through, for example, the education system, the welfare system, and the economy, but all are characterised by interconnectedness, complexity and individualisation (Beck and Beck-Gernsheim, 2002; Luhmann, 1992). A given society's freedom of information, economic growth and welfare system, or allowances for travel are significant dimensions of globalisation as are increasing economic gaps between geographic regions and among social groups within societies, increasing exploitation of resources, migration, civil and international wars, and increasing security concerns. The United Nations Development Programme describes a number of central challenges facing humans when dealing with globalisation processes, such as addressing regional and national inequities, supporting human rights, reducing poverty, maintaining security, and achieving sustainability (UNDP, 1999:2f).

\section{Rapid social change}

The second characteristic of a global society can be described in a temporal dimension in that globalisation entails a 'shrinking of time' (UNDP, 1999:1) as well as an acceleration of social change as both causes and consequences of global change (Luhmann 1998). Enhanced communication can be perceived as threatening because it accelerates the life-rhythms of humankind. In some parts of the world, the speed of social change has surpassed the generational turnover that previously characterised conflicts between modernity and tradition (Giddens, 1990).

\section{Life is losing its anchor in space}

Globalisation delimits space in new ways. Through new media and the internet, distance acquires a new meaning. People can witness events without being present for them. At the same time, the importance of the local as a space for action (for example in family-planning, in the food-industry and in access to water) still prevails. The British sociologist Robertson (1995), for instance, has spoken of the idea of 'glocal contexts'. New structures are also arising which are no longer dominated by nation states or hierarchical order, but organised in reciprocal networks (Castells, 1996; 1997 and 1998).

\section{Societies are increasingly multicultural and multireligious}

The distinction between what seems strange or familiar is no longer only a geographical or spatial issue, and this hints at social fragmentation in a global world (Appadurai, 1990). Gaps become more visible between poverty and wealth, across hemispheres as well as within nations. Societies are becoming more and more multicultural, multilingual and multi-religious (Bertelsmann Stiftung, 2009). The necessity of learning an international lingua franca such as English or regional lingua franca such as Spanish, Mandarin or Swahili is increasing due to the need for global communication. Increasingly these languages are only loosely connected 
with their original cultural backgrounds, creating new hybrid forms and Creole cultures (Babha, 1994; Young, 1995) or cosmopolitanisms (Appiah, 2006).

All of the developments described above are universal, but have diverse manifestations in different regions and cultural contexts.

\section{The Challenges of Globalisation for Individual Learning}

What do these developments mean for learning? ${ }^{2}$

\section{Knowledge and the lack of knowledge}

In a situation of increasing knowledge, the roles played by education and by knowledge itself become increasingly important, as do the complex interactions between them. For instance, unemployment has a strong negative correlation with low literacy levels, particularly in the context of the emergence of 'knowledge societies' (see Böhme and Stehr, 1986). In other words, as knowledge in a society increases, individuals' lack of knowledge increases proportionately. That is, collective knowledge and individual non-knowledge are increasing simultaneously. People therefore have to learn to make their decisions in the context of a lack of knowledge and to adapt to the possibility that unintended consequences may result. The German philosopher Odo Marquard speaks in this context about Inkompentenzkompensationskompentenz, a new German word created by him which means the necessity of a competence which compensates for incompetence (see Marquard, 1974 and 1981).

\section{Certainty and uncertainty}

The rapid speed of temporal change also forces us to deal with a structural lack of time, in personal agendas as well as in actions of nations or enterprises (Rosa, 2005; Rosa and Scheuermann, 2009). As a result, an ability to deal with time pressure and uncertainty is increasingly important, as is the capacity to learn how to distinguish between those things which are certain and those which are uncertain. Especially for education, time is becoming an issue.

\section{Local relationships and new meanings of space}

We also have to learn to deal with the implications of new meanings of space. If space is no longer about a clear local relationship, then the ability to imagine the consequences which can result from acting in other regions and to cultivate crossglobal ways of behaviour is increasingly important.

\section{Familiarity and strangeness}

From a social perspective we have to learn that familiarity and strangeness are also no longer categories with geographical connotations. In Europe and North America over the last few decades, the main emphasis in this domain has been on how to integrate students from diverse languages and cultural backgrounds in classrooms. 
While these efforts are important and necessary, notions of diversity must also be extended to include social relationships with people who are located elsewhere and an ability to deal conceptually with otherness and hybrid cultures (Wulf, 2002). The rapprochement of global and multicultural perspectives is obvious in this regard.

\section{Competencies for a Global Society}

Which competencies are needed to respond to these insights? ${ }^{3}$

\section{Dealing with knowledge and the lack of knowledge}

As knowledge increases in volume and importance, there is first of all more to learn. There are three kinds of knowledge to distinguish in this context. The first is basic knowledge (or basic competencies) which forms the foundation for such specialised learning and specialised skills as literacy, mathematical literacy and natural sciences. Such basic knowledge, which is usually provided by schools, is becoming standardised over the globe. Secondly, higher level competencies, such as problemsolving and knowing how to learn, are becoming increasingly important, especially as they provide the possibility for lifelong learning. Thirdly, there are types of knowledge that are culturally specific and not usually within the province of schools. This might include, for example, health, food and its preparation, attitudes and beliefs (regarding religion and ethics as well as science and technology), and lifestyles, which are most often taught informally within families and societies.

In general, knowledge about globalisation and related phenomena are not yet a common part of school-based learning. Nevertheless, people need to know about topics such as the UN Millennium Development Goals, living conditions in other parts of the world, and the emerging consensus on human rights, including children's rights, which are identified in international conventions (see Osler et al, 2002; Bourn, 2008b; Asbrand and Scheunpflug, 2006; Sander, 2004).

Because the more there is to know, the more an individual does not know, people must be aware that they can be wrong, even if they are generally knowledgeable. Also, a lot of available information is contradictory and therefore can be confusing. To take a very simple example: most research suggests that mobile phones are not damaging to health, but some research also points to a risk of cancer. Of course, in comparison to this, there are much more difficult and complex decisions to be made under far more obscure conditions. Education therefore has to assist in supporting the process of decision-making under conditions of a relative lack of knowledge. Traditionally, school curricula have supported linear processes for problem solving and the creation of one-dimensional solutions, but these approaches do not develop the competencies really needed for addressing complex problems. Cultivating the ability to change perspectives is a necessary challenge for today's learners (Merryfield, 1997:3; Scheunpflug and Schröck, 2002; Nodding, 2005:48). 


\section{Dealing with uncertainty}

Today social change has become faster than the life-span of one generation, making uncertainty one of the dominant feelings in a global society. Methods for structuring complex problems and dealing with ambiguity are therefore important skills for today (see Mundy, 2007:10ff). Learning must also involve the opportunity to build one's own opinions. Although there are some decisions one can only make by oneself, it generally helps to assess the possibilities and to react. With respect to problems which individuals cannot solve on their own, it is also necessary to show constructive possibilities for dealing with them individually. For example, one needs to learn when to search for more information and when it would be better to stop. One needs to reflect on the process of decision-making, too. One dimensional solutions for dealing with the complexity of a global world society are exposed very quickly.

\section{Working with national and transnational networks}

In a global society, knowing how to identify networks (cf. Bourn, 2008a:10) is an important competency. To integrate oneself into a network is difficult, especially if the network is dominated by languages or cultural backgrounds different from one's own. This can be even more challenging because, through the influence of the mass media, people can develop distorted ideas about life in other regions of the world. In the present day, competencies in networking must now also include communicating in both concrete and virtual spaces (e.g. email contacts, blogs, Second Life, and social networking sites such as Myspace and Facebook) as well as the ability to differentiate between them.

\section{Understanding of diverse cultures and religions, language and inter-cultural communication}

Education should offer knowledge about different lifestyles, cultures and religions. Youth in all parts of the world play, have parents and friends, go to school, and have joys and sorrows. These commonalities help learners connect the experiences of others to their own lives, making it easier to accept differences as well as to learn to take on new perspectives (c.f. Noddings, 2005:48ff; Merryfield, 1997).

An ability to communicate effectively is increasingly important, and individuals have to acquire a refined language code and inter-cultural competence. While it is important to have the skills to communicate politely and acceptably in one's mother tongue, for instance, it is also important to know how to speak about and with others without racism and paternalism. Unfortunately, many children do not learn this at home. Competencies in foreign languages are also needed. This enables people to speak in a way that others from different language contexts can understand, to respect the cultural variety of languages, and to be sensitive to inter-cultural conflicts (see Kramsch, 2006 regarding the links between culture and language).

34 International Journal of Development Education and Global Learning 3(3) 2011 
Table 1: Summary - Competencies Required by Globalisation

\begin{tabular}{|c|c|c|c|}
\hline & Globalisation & Consequences & $\begin{array}{l}\text { Competencies } \\
\text { Required }\end{array}$ \\
\hline $\begin{array}{l}\text { Factual } \\
\text { Dimension }\end{array}$ & $\begin{array}{l}\text { Pluralities of } \\
\text { globalisation } \\
\text { Increasing } \\
\text { complexity }\end{array}$ & $\begin{array}{l}\text { Increasing knowledge } \\
\text { and lack of knowledge }\end{array}$ & $\begin{array}{l}\text { Literacy, math and } \\
\text { sciences } \\
\text { Knowledge about } \\
\text { globalisation } \\
\text { Local knowledge } \\
\text { Ability to deal with a lack } \\
\text { of knowledge }\end{array}$ \\
\hline $\begin{array}{l}\text { Temporal } \\
\text { Dimension }\end{array}$ & Acceleration & $\begin{array}{l}\text { Increasing certainty and } \\
\text { uncertainty }\end{array}$ & $\begin{array}{l}\text { Information seeking and } \\
\text { structuring } \\
\text { Tolerance to ambiguity }\end{array}$ \\
\hline $\begin{array}{l}\text { Spatial } \\
\text { Dimension }\end{array}$ & $\begin{array}{l}\text { Losing anchor } \\
\text { in space } \\
\text { Glocalisation } \\
\text { Changing nature of } \\
\text { networks }\end{array}$ & $\begin{array}{l}\text { Increasing local } \\
\text { relatedness and } \\
\text { spacelessness }\end{array}$ & $\begin{array}{l}\text { Thinking and working in } \\
\text { networks } \\
\text { Thinking and working in } \\
\text { virtual spaces }\end{array}$ \\
\hline $\begin{array}{l}\text { Social } \\
\text { Dimension }\end{array}$ & $\begin{array}{l}\text { Multiculturalism and } \\
\text { multi-religiousness }\end{array}$ & $\begin{array}{l}\text { Increasing familiarity and } \\
\text { strangen }\end{array}$ & $\begin{array}{l}\text { Knowledge about diverse } \\
\text { lifestyles, cultures and } \\
\text { religions } \\
\text { Refined language code } \\
\text { - Foreign languages and/or } \\
\text { English } \\
\text { Intercultural competency } \\
\text { and ability to see from } \\
\text { other perspectives }\end{array}$ \\
\hline
\end{tabular}

These competencies are necessary not only to cope with globalisation but also to build global peace, social justice and sustainability. At a time when globalisation and nationalism are often linked, developing individuals' awareness of complex global issues is often seen as highly political and value-laden (Parker, 2008). Perspectives from international ethics and global citizenship, which are based on strong philosophical foundations, are therefore the foundations for global education.

\section{Towards a Research-based Approach to Global and Transnational Teacher Education}

These challenges have particular consequences for teachers: they have to learn to conceptualise globalisation and to develop these competencies themselves, and they must also learn to teach them (cf. Merryfield, 1997; Merryfield, Jarchow and Pickert, 1997; Cognan and Grossmann, 2009; Räsänen, 2008 and 2009; Hartmeyer, 2008:103). These challenges call for a research-based approach to teacher education. In my understanding, this term means two things: 
All aspects of teacher education should be based on research. This helps to provide teacher training which is relevant to the complex future challenges of our societies.

- New teachers should be involved in action research and encouraged to see research as a key part of their training. This is important for fostering professional curiosity and deep reflection on the needs of beginning teachers (see Ruddock, 1985).

There is a plethora of existing research which looks at the professional competencies of teachers and their role in teacher education (cf. Achtenhagen et al, 2009; Grossmann and McDonald, 2008; Schmidt et al, 2010). In terms of building a research-based approach to teacher education, the work of Shulmann $(1998 ; 2006)$ and Baumert and Kunter (2006) is particularly valuable. According to Baumert and Kunter, for instance, teachers' knowledge is accompanied by (a) value commitments, epistemological beliefs and worldviews as well as (b) motivations and (c) professional self regulation. Relating the competencies needed in a globalised society with the domains of teachers' competencies gives a systematic assessment about what is needed in teacher education. What do we know from research about these fields?

\section{Professional knowledge}

What professional knowledge do teachers need to approach global education?

Content knowledge: Since the 1970s in Europe there have been many attempts to write curricula in global learning and to include them in national or state curriculum guidelines (cf. Scheunpflug and Seitz, 1995; Hartmeyer, 2008; Mundy, 2007: 17 and 101; Tye, 2009; Merryfield, 2009; on concepts of knowledge see Merryfield, 1997:7; OFSTED 2006 and 2010). In Germany, a national curriculum on global learning was launched in 2006 (KMK, 2007). This framework was approved by all federal ministers and integrated into the curriculum of all states. The first instrument attempting to test global competencies was constructed around the same time (Rost et al, 2003; Rost 2004 and 2005).

Two studies in the Netherlands also showed the influence of professional knowledge and individual motivation on the implementation of global learning (Beneker and van derVaart, 2008). The majority of the interviewed teachers complained about the difficulty in selecting content and materials due to their lack of knowledge. They also often felt a lack of support from their colleagues. Similar problems were identified in a recent German study. Obermaier and Schrüfer (2009) asked student teachers to explain why there are famines in Africa. The results show that their explanations were clearly oversimplified, with interviewees citing internal factors such as climate, overpopulation, political crises, and lack of industry. Global relations, such as the international economic order or world trade agreements, on the other 
hand, were not mentioned. This suggests that mass media played a greater role in the construction of their knowledge about these issues than validated information or informed theories. Further research is needed on what teachers know about global issues and whether they use this knowledge in classroom.

Using global perspectives in the classroom: There has been very little research about the efficiency of teaching global learning. Research is just beginning to explore the effects of these kinds of pedagogical arrangements. Vanessa Andreotti (Andreotti and de Souza, 2008; Andreotti, 2010) and Barbara Asbrand (Asbrand, 2009), for example, have shown that teaching about development does not necessarily lead to the prevention of prejudices and paternalism, and can even re-enforce them.

Evidence suggests that many teachers do not feel qualified to deal with the complexity of global issues and are therefore reluctant to do so. A multi-country European study on citizenship education suggested that teacher training was seriously lacking in this regard (Scheerens, 2009:326). Recently published research from Canada has also shown that even teachers trained in global issues felt pressured by the political dimension of global education (Pike, 2008; O'Sullivan, 2008). In a survey in Germany, teachers described these issues as 'demanding' and 'very complex', therefore legitimating their omission in the classroom (Stein, 2008). Furthermore, teachers in only 2.3 per cent of all schools in Bavaria claimed to have done a classroom project on global issues in the year 2006-2007 (Stein, 2008), despite the fact that teachers in 12 per cent of the schools had been intensively trained to do so. Findings from the UK show that only 9 per cent of students claimed to have had any experiences with exploring new perspectives in school (IPSOS MORI, 2008).

In relation to dealing with a lack of relevant knowledge of global issues specifically, we do not yet have empirical findings about how to create such learning in classrooms, although some useful models have been suggested. For instance, could Cognan and Grossman's (2009) 'characteristics of globally minded teachers' be pragmatically achieved? David Hansen's (2008) proposal for a cosmopolitan curriculum could also be a useful approach.

\section{Values}

Values are one component of teacher competencies. Teachers' values and their often hidden epistemological knowledge as well as their subjective theories influence their teaching objectives and classroom behaviours. We know very little about teachers' values in regard to global education specifically. Moreover what we do know only provides glimpses of some groups or individual teachers, so much more work is needed in this area.

\section{Attitudes towards global issues}

In Europe a number of opinion polls have revealed useful information about general public attitudes towards global issues, although these do not give data 
specifically on teachers. In Germany, for example, a recent poll showed that 78 per cent of the adult population had never heard of the Millennium Development Goals (compared to 58\% in Sweden) (Eurobarometer, 2007). Only 10 per cent of Germans agreed that target countries should participate in decisions about the uses of development aid (compared to $24 \%$ in Sweden) (Eurobarometer, 2007). These results indicate that a Eurocentric and unilateral view of development is still dominant among the general population, but we do not know whether teachers are similar or different in this regard. By comparing countries in Europe we see that in countries invest significantly in global learning, such as Sweden and the Netherlands, the population shows much more positive attitudes toward development issues than in countries, such as Spain or France, where public engagement is low (Eurobarometer, 2007; for data from the 1990s see Smillie and Helmich, 1998). However, we do not know whether these attitudes are a result of engagement in global learning, or if engagement in global learning is instead a result of pre-existing attitudes.

\section{Influencing the attitudes of teachers}

According to Lowenstein (2009), research on influencing teachers' perspectives towards multiculturalism 'is a long, labor-intensive process'. Short interventions and unaccompanied travel visits to other countries 'have not been characterised as helpful but, rather, as hurtful in perpetuating in-service teachers' stereotypes' (Lowenstein, 2009:176ff; see also Scheunpflug, 1997) Conditions effective in changing attitudes of teachers towards global issues and multicultural aspects unfortunately have not yet been empirically demonstrated (Abs et al, 2007), but opportunities for participation and self efficacy probably play an important role (for often negative experiences of participation see Bertelsmann-Stiftung, 2007; Abs et al, 2007). A five year program for citizenship education in Germany did not show any significant effects on the values and beliefs of individual students (with the exception of their self efficiency concept in regards to politics), and there was little effect on the school level despite more opportunities for participation and better conflict resolution (Abs et al, 2007:56).

\section{Epistemological knowledge}

More research is also needed to explore teachers' epistemological knowledge of global and international issues. This, in turn, would require research about the broader epistemological bases of the competencies needed for globalisation. The concept of 'epistemological knowledge' highlights the importance of understanding both the limits and the validity of knowledge. There is evidence for the hypothesis that global competencies are related to understanding complexity, tolerance of ambiguity and recognition of otherness. Questions to be posed include the following:

How do competencies lead to social and global problem-solving?

38 International Journal of Development Education and Global Learning 3(3) 2011 
Do the epistemological beliefs of teachers correlate with the degree of cognitive activation of students?

How is this activation related to didactic settings in the classroom?

When compared to the amount of attention given to values in regard to teacher competencies, knowledge about these values in regard to global issues is significantly under-researched.

\section{Motivational orientations}

Tschannen-Moran, Woolfolk Hoy and Hoy (1998) showed that teachers with higher self efficacy expectations showed better motivation for teaching, better preparation for teaching, and better support for students in general. However, we do not yet know much about the self efficacy expectations of teachers specifically in regard to acting globally and internationally or to transferring this into the classroom. In order to have experiences of self efficiency related to global and multicultural settings, I would suggest that a certain degree of exposure to situations which are globally framed is important.

In Germany, for instance, the majority of primary and secondary school teachers are white, non-migrant, and middle-class. I have personally experimented with a programme of 'travelling to the unknown Germany' ('Germanistan') in teacher education in an effort to provide authentic insights into an unknown society. These kinds of programmes are difficult to implement on a large scale, however, as they run the risk of reinforcing prejudices rather than leading to better understanding. There are also sometimes problems in Germany with exposing primary and secondary trainee teachers to international seminars held in English, French or Spanish, because they are too shy to participate in language that is not their mother tongue.

\section{Self-regulation}

The capacity to regulate one's actions, and especially the responsibility for managing personal resources, is an important component of teacher professionalism. There is evidence to suggest that in many cases teachers use their self-regulation skills to avoid dealing with global issues in the classroom. However, more research is needed to explore the relationships between teachers' self-regulation and engagement with global issues. For example, we know that there are 50 per cent more teachers in Germany who express an interest in intercultural issues than who show a willingness to actually participate in related in-service training. This is in contrast to subject-related areas where such a large gap is not found (Abs et al, 2007:40f). This indicates that there may be significant anxiety amongst teachers about working with issues with which they do not feel comfortable.

Based on these findings, I propose that 'biographical learning' about teachers' own learning paths towards developing a global and multicultural perspective is very important (cf. Merryfield, 1997:14; Franz et al, 2009). Biographical learning links global 
issues and its challenges to the life of the learner and provokes reflection on their own anxieties, hopes and visions. More research is needed to explore these issues, as are new approaches to understanding the biographical learning of teachers.

\section{Final Remarks}

I do not know how the teacher in whose neighbourhood a Nepalese person had not been seen for 17 generations achieved the competence in global education and multicultural education to react as she did.

In his writings Idea for a Universal History with a Cosmopolitan Purpose (1784) and Towards Perpetual Peace (1795) the philosopher Immanuel Kant reflected on how to achieve what today we would call global social justice. Although he did not expressly work on global education, in his broader work on education he suggests education should be about enlightening learners. Global education is therefore not about changing the world, but about promoting learning. Even if the challenges of globalisation are overwhelming, it is up to each individual to learn about them, as the pupils in the classroom talking about Nepal did. Leading learners to think may be one of the major purposes of global learning in teacher education.

Georg Christoph Lichtenberg, a German philosopher and the first professor of experimental physics in Europe said about the objectives of education that 'being irritated is better than sticking with a simple order of thoughts' (cf. Lichtenberg, 1899/1966ff). Maybe it will be the distinguished work of teacher education to contribute to good irritations in a global perspective.

Annette Scheunpflug has a Chair in the Philosophy of Education at the FriedrichAlexander-University of Erlangen-Nuremberg in Germany. Global learning is one of her key areas of research interest.Email: Annette.Scheunpflug@ewf.uni-erlangen.de

\section{References}

Achtenhagen, F., Oser, Fritz K. and Renold, U. (2009) (ed.) Teachers' Professional Development. Aims, Modules, Evaluation. Rotterdam: Sense.

Abs, H., Roczen, N. and Klieme, E. (2007) Abschlussbericht zur Evaluation des BLK-Programms „Demokratie lernen und leben”. Frankfurt (Deutsches Institut für Internationale Pädagogische Forschung). (Materialien zur Bildungsforschung, Bd. 19).

Andreotti, V. (2010) Global Education in the '21st Century': two different perspectives on the 'post-' of postmodernism. International Journal of Development Education and Global Learning 2(2) p. 5-22.

Andreotti, V. and Souza, L. (2008) Translating Theory into Practice and Walking Minefields. Lessons from the project 'Through Other Eyes'. International Journal of Development Education and Global Learning. 1(1) p. 23-36.

Albert, M. and Hilkermeier, L. (ed.) (2004) Observing International Relations: Niklas Luhmann and World Politics. London: Routledge.

Appadurai, A. (1990) Disjuncture and Difference in the Global Culture Economy. In M. Featerstone (ed) Global Culture: Nationalism, Globalization and Modernity. London: Sage.

Appiah, K. A. (2006) Cosmopolitsm. Ethics in a World of Strangers. London: W.W. Norton.

Asbrand, B. and Scheunpflug, A. (2006) Global Education and Education for Sustainability. Environmental Education Research 12(1) p. 33-47.

Asbrand, B. (2009) Wissen und Handeln in der Weltgesellschaft. Eine qualitativ-rekonstruktive Studie zum Globalen Lernen in der Schule und in der außerschulischen Jugendarbeit. Münster. 
Bhabha, H.K. (1994) The Location of Culture. London: Routledge.

Baumert, J. and Kunter, M. (2006) Professionelle Kompetenz von Lehrkräften, in: ZfE 9 (2006), H. 4, 469-520.

Beck, U. (1999) What is Globalization? London: Blackwell.

Beck, U. and Beck-Gernsheim, E. (2002) Individualization: Institutionalized Individualism and its Social and Political Consequences. London: Sage.

Béneker, T. and van der Vaart, R. (2008) Global Education in the Dutch Context. ZEP - Zeitschrift für internationale Bildungsforschung und Entwicklungspädagogik. 31. Jg. H.1, 27-31.

Bertelsmann Stiftung (ed.) (2009) What the World Believes. Analyses and Commentary on the Religion Monitor 2008. Gütersloh: Bertelsmann.

Bertelsmann Stifung (2007) (ed.) Kinder- und Jugendbeteiligung in Deutschland. Gütersloh: Bertelsmann.

Blossfeld, H.P. and Mills, M. (2003) Globalization, uncertainty and changes in early life courses. Zeitschrift für Erziehungswissenschaft 6: 188-218.

Blossfeldt, H.P., Raab, M., Ruland, M., Schönberger, B., Hofäcker, D., Buchholz, S. and Schmelzer, P. (2008) Globallndex. A sociological approach to globalization measurement. International Sociology 23 p. 596-629.

Böhme, G. and Stehr, N. (ed.) (1986) Knowledge Society. The Growing Impact of Scientific Knowledge on Social Relations. Dordrecht: Reidel.

Bourn, D. (2008a) Global Skills. London: LSIS.

Bourn, D. (2008b) Development education: Towards a re-conceptualisation. International Journal of Development Education and Global Learning 1(1) p. 5-23.

Castells, M. (1998) The Information Age: Economy, Society, and Culture, Volume 3: End of Millennium. Oxford: Blackwell.

Castells, M. (1997) The Information Age: Economy, Society, and Culture, Volume 2: The Power of Identity. Oxford: Blackwell.

Castells, M. (1996) The Information Age: Economy, Society, and Culture, Volume 1: The Rise of the Network Society. Oxford: Blackwell.

Cognan, J.J. and Grossman, D.L. (2009) Characteristics of Globally Minded Teachers: A Twenty-First Century View. In T. Fuss Kirkwood-Tucker (ed) Visions in Global Education. The Globalization of Curriculum and Pedagogy in Teacher Education and Schools. Perspectives from Canada, Russia and the United States. New York: Peter Lang. Dieter, H. (2005) Die Zukunft der Globalisierung; Zwischen Krise und Neugestaltung, Baden-Baden: NomosVerlagsgesellschaft.

Dolby, N. and Rahman, A. (2008) Research in International Education. Review of Educational Research 78(3) p. 676-727.

Eurobarometer 280/ Wave 67.1 (2007) European Development Aid. Brussels: European Commission.

Franz, J., Frieters, N., Scheunpflug, A., Tolksdorf, M. and Antz, E. M. (2009) Generationen lernen gemeinsam. Theorie und Praxis intergenerationeller Bildung. EB Buch 28. Bielefeld: Bertelsmann.

Kirkwood-Tucker, T.F. (ed.) (2009) Visions in Global Education. The Globalization of Curriculum and Pedagogy in Teacher Education and Schools. Perspectives from Canada, Russia and the United States. New York: Peter Lang. Giddens, A. (1990) The Consequences of Modernity. Stanford: Stanford University Press.

Grossmann, P.L. and McDonald, M. (2008) Back to the future. Directions for research in teaching and teacher education. American Educational Research Journal 45(1) p. 184-205.

Hansen, D. T. (2008) Curriculum and the idea of a cosmopolitan inheritance. Journal of Curriculum Studies, 40(3): 289-312.

Hartmeyer, H. (2008) Experiencing the World. Global Learning in Austria: Developing, Reaching out, Crossing Borders. Münster: Waxmann.

IPSOS Mori (2008) Young People Omnibus 2008 (Wave 14). Young People's Experiences of Global Learning. Our Global Future. How can education meet the challenge of change? London: DEA.

Kant, I. (1784) Idee zu einer allgemeinen Geschichte in weltbürgerlicher Absicht [Idea for a Universal History with a Cosmopolitan Purpose]. Kant Studienausgabe, Vol. VI, edited by W. Weischedel, Darmstadt 1964.

Kant, I. (1765) Zum ewigen Frieden. Ein philosophischer Entwurf [Perpetual Peace]. Kant Studienausgabe, Vol. VI, edited by W. Weischedel, Darmstadt 1964.

KMK 2007 [Ständiges Sekretariat der Kultusministerkonferenz der Länder] (2007) Global Development Education. A Cross-Curricular Framework in the Context of Education for Sustainable Development. Bonn: KMK http:// 
www.globaleslernen.de/coremedia/generator/ewik/de/Downloads/Dokumente/Orientierungsrahmen_20f_C3_BCr _20Globales_20Lernen_20-_20englisch.pdf.

Kramsch, C. (2006) Culture in Language Teaching. In H. Leth Andersen, K. Lund and K. Risager (eds) Culture in Language Learning. Aarhus, DK: Aarhus University Press.

Lang-Wojtasik, G. (2003) Concepts of global learning - the German debate. Development Education Journal 10(1) p. 25-27.

Lang-Wojtasik, G. (2009) Difference as a Contribution to Education Theory and Global Learning from a German Perspective. International Journal of Development Education and Global Learning 1(3): p. 5-21.

Lauder, H., Brown, P., Dillabough, J.-A., Halsey, A.H. (2006) (ed.) Education, Globalization and Social Change. Oxford: Oxford University Press.

Lichtenberg, Georg, C. (1899/1966) Aphorismen. Frankfurt/Main: Reclam.

Lowenstein, K.L. (2009) The Work of Multicultural Teacher Education: Reconceptualizing White Teacher Candidates as Learners. Research in International Education 79(1) p. 163-196.

Luhmann, N. (1975) Die Weltgesellschaft. In Luhmann, N.: Soziologische Aufklärung, Band 2. - Opladen, 51-71. Luhmann, N. (1982) The World Society as a Social System, International Journal of General Systems 8 (1982), 131-138.

Luhmann, N. (1992) Societal Complexity. In G. Szell (ed) Concise Encyclopedia of Participation and Co-management. Berlin/New York: De Gruyter.

Luhmann, N. (1994) Temporalisierung von Komplexität. Zur Semantik neuzeitlicher Zeitbegriffe. In: ib.: Gesellschaftsstruktur und Semantik, Band 1, 235-300.

Luhmann, N. (1995) Social Systems. Stanford: Stanford University Press.

Luhmann, N. (1997) Globalization or World Society: How to Conceive of Modern Society? International Review of Sociology 7(1) p. 67-79.

Marquard, O. (1974) Inkompetenzkompensationskompetenz. In: Philosophisches Jahrbuch. Nr. 81, 1974, 341-349. Marquard, O. (1981) Inkompetenzkompensationskompetenz? Über Kompetenz und Inkompetenz der Philosophie. In: Marquard, O.: Abschied vom Prinzipiellen. Philosophische Studien, 23-38. Stuttgart: Reclam.

Mason, M. (ed.) (2008) Complexity Theory and the Philosophy of Education. London: Blackwell.

Merryfield, M.M. (1997) A Framework for Teacher Education in Global Perspectives. In M.M. Merryfield, E. Jarchow and S. Pickert (eds) Preparing Teachers to Teach Global Perspectives. A Handbook for Teacher Educators. Thousand Oaks: Corwin Press.

Merryfield, M.M. (2009) Moving the Centre of Global Education: From Imperial Worldviews That Divide the World to Double Consciousness, Contrapuntal Pedagogy, Hybridity, and Cross-Cultural Competence. In T. Fuss Kirkwood-Tucker (ed) Visions in Global Education. The Globalization of Curriculum and Pedagogy in Teacher Education and Schools. Perspectives from Canada, Russia and the United States. New York: Peter Lang.

Merryfield, M.M. and Duty, L. (2008) Globalization. In J. Arthur, I. Davies, and C. Hahn (eds) The SAGE Handbook of Education for Citizenship and Democracy. London: Sage.

Merryfield, M.M., Jarchow, E. and Pickert, S. (eds) (1997) Preparing Teachers to Teach Global Perspectives. A Handbook for Teacher Educators. Thousand Oaks: Corwin Press.

Mundy, K. (2007) Charting Global Education in Canada's Elementary Schools: Provincial, District and School Level Perspectives. Toronto: UNICEF Canada.

Noddings, N. (ed.) (2005) Educating Citizens for Global Awareness. New York: Teachers College Press.

O'Sullivan, M. (2008) You Can't Criticize What You Don't Understand: Teachers as Social Change Agents in Neo Liberal Times. In M. O'Sullivan and K. Pashby (eds) Citizenship Education in the Era of Globalization. Canadian Perspectives. Rotterdam: Sense Publisher.

Obermaier, G. and Schrüfer, G. (2009) Personal concepts on 'Hunger in Africa'. International Research in Geographical and Environmental Education 18(4) p. 245-251.

OFSTED [Office for Standards in Education, Children's Services and Skills] (2006) Towards consensus? A report on Citizenship Education in Schools. Manchester: OFSTED.

OFSTED (2010) Citizenship established? Citizenship in schools 2006/09. Manchester: OFSTED.

Osler, A. and Vincent, K. (2002) Citizenship and the Challenge of Global Education. Stoke on Trent: Trentham.

Parker, W. (2008) International Education. What's in a name? Phi Delta Kappan 90(3) p. 196-202.

42 International Journal of Development Education and Global Learning 3(3) 2011 
Pike, G. (2008) Citizenship education in a global context. In M. O'Sullivan and K. Pashby (eds) Citizenship Education in the Era of Globalization. Canadian Perspectives. Rotterdam: Sense Publisher.

Prestowitz, C. (2005) Three Billion New Capitalists. The Great Shift of Wealth and Power to the East. New York: Basic Books.

Räsänen, R. (2008) In search of Global Learning in teacher education. Zeitschrift für internationale Bildungsforschung 31(1) p. 30-35.

Räsänen, R. (2009) Global learning: transformative global education and learning in teacher education in Finland. International Journal of Development Education and Global Learning 1(2): 25-40.

Robertson, R. (1992) Globalization: Social Theory and Global Culture. London: Sage.

Robertson, R. (1995) Glocalization. In: M. Featherstone, S. Lash and R. Robertson (ed.) Global Modernities. London: Sage.

Rosa, H. (2005) Beschleunigung. Die Veränderung der Temporalstrukturen in der Moderne, Frankfurt a.M.: Suhrkamp.

Rosa, H. and Scheuermann, W. (2009) High-Speed Society: Social Acceleration, Power and Modernity. University Park, PA: Penn State University Press.

Rost, J., Lauströer, A. and Raack, N. (2003) Kompetenzmodelle einer Bildung für Nachhaltigkeit, Praxis der Naturwissenschaften - Chemie in der Schule, 8, 52, 2003, 10-15.

Rost, J. (2004) Competencies for global learning. The Development Education Journal 11(1) p. 6-8.

Rost, J. (2005) Messung von Kompetenzen globalen Lernens. Zeitschrift für internationale Bildungsforschung und Entwicklungspädagogik, 2, 28, 2005, 14-18.

Ruddock, J. (1985) Teacher research and research-based teacher education. Journal of Education for Teaching 11(3) p. 281-289.

Sander, W. (2004) Incitement to freedom: competencies of political education in a world of difference. The Development Education Journal 11(1) p. 9-11.

Scheerens, J. (2009) Informal Learning of Active Citizenship at School. An International Comparative Study in Seven European Countries. Berlin, Heidelberg: Springer.

Scheuermann, W.E. (2006) Globalization. In: Stanford Encyclopaedia of Philosophy. Stanford: The Centre for the Study of Language and Information. Retrieved from http://plato.stanford.edu (2 May 2009).

Scheunpflug, A. (1996/ 2003b) Globalization as a Challenge to Human Learning. In: Education, Vol. 54, 1996, 716.

Scheunpflug, A. (1997) Cross-cultural encounters: a possibility of gradually overcoming xenophobia? International Review of Education 43(1) p. 109-116.

Scheunpflug, A. (2003) Globalisierung und Erziehungswissenschaft. In: Zeitschrift für Erziehungswissenschaft, 6. Jahrgang, Heft 2, 2003, 159-172.

Scheunpflug, A. and Schröck, N. (2002) Globales Lernen. Stuttgart: Brot für die Welt.

Scheunpflug, A. and Seitz, K. (1995) Die Geschichte der entwicklungsbezogenen Bildungsarbeit. Zur pädagogischen Konstruktion der Dritten Welt, 3 vol. Frankfurt/M.: IKO.

Schmidt, W. H., Blömeke, S. and Tatto, M. T. (2010) Teacher Preparation from an International Perspective. New York: Teachers College Press.

Sen, A. (1999) Development as Freedom. Oxford: Oxford University Press.

Shulman, L. S. (1986) Those who understand: knowledge grows in teaching. Educational Researcher 15(2) p. 414.

Shulman, L. S. (2006) The Wisdom of Practice. Essays on Teaching, Learning and Learning to Teach. San Francisco: Jossey-Bass.

Smillie, I. and Helmich, H. (1998) Public Attitudes and International Cooperation. Paris: OECD.

Spring, J. (2008) Research on Globalization and Education. Review of Educational Research 78(2) p. 330-363.

Stein, M. (2008) Werteerziehungsansätze an weiterführenden Schulen in Bayern. In: Bayerisches Staatsministerium für Unterricht und Kultus (ed.) Praxishandbuch zur Werteerziehung "Werte machen stark." Donauwörth: Auer, 54-67.

Stichweh, R. (1995) Zur Theorie der Weltgesellschaft. In: Soziale Systeme, H. 1, 1. Jg., $29-45$.

Stichweh, R. (1996) Science in the system of world society. Social Science Information 35(2) p. 327-340.

Stieglitz, J. E. (2002) Globalization and Its Discontents. New York: Norton. 
Tye, K. A. (2009) A history of the global education movement in the United States. In T.F. Fuss Kirkwood-Tucker (ed) Visions in Global Education. The Globalization of Curriculum and Pedagogy in Teacher Education and Schools. Perspectives from Canada, Russia and the United States. New York: Peter Lang.

Tschannen-Moran, M., Woolfolk Hoy, A.W. and Hoy, W.K. (1998) Teachers efficacy: its meaning and measure. Review of Educational Research 68 p. 202-248.

UNDP [United Nations Development Program] (1999) Bericht über die menschliche Entwicklung: Globalisierung mit menschlichem Antlitz. Herausgegeben von der Deutschen Gesellschaft für die Vereinten Nationen e.V. - Bonn. VBW [Verband der Bayerischen Wirtschaft] (2008): Bildungsrisiken und -chancen im Globalisierungsprozess Jahresgutachten 2008, Wiesbaden: vs.

Weber, E. (2007) Globalization, 'glocal' development and teachers' work in South Africa: a research agenda. Review of Educational Research 77(3) p. 279-310.

Wulf, C. (2002) Globalisierung und kulturelle Vielfalt. Das Andere und die Notwendigkeit anthropologischer Reflexion. In: Wulf, C. and Merkel, C. (ed.) Globalisierung als Herausforderung der Erziehung. Theorien, Grundlagen, Fallstudien. - Münster, 75-100.

Yang, R. (2003) Globalisation and higher education development: a critical analysis. International Review of Education 49(3-4) p. 269-271.

Young, R. (1995) Colonial Desire, Hybridity in Theory, Culture and Race. London, New York.: Routledge.

\section{Notes}

1 The following paper is a revised version of a keynote address given at Indiana University in Bloomington, Indian, USA in May 2009. I would like to thank my colleagues for their helpful comments and assistance with proofreading, as well as the anonymous reviewers for their helpful comments.

2 See with focus on globalisation in international Education Dolby and Rahmann (2008); for the educational system Lauder et al. (2006); for higher education Yang (2003); for developing countries Weber (2007); see with focus on aspects of global education Mason 2008; Merryfield and Duty 2008; Noddings 2005; Scheunpflug and Schröck 2002; Lang-Wojtasik 2003; Bourn 2008b; Spring 2008.

3 For further discussion, see also Scheunpflug (1996/ 2003b) and Lang-Wojtasik (2009).

\section{Also from Trentham}

\section{IDENTITY TEXTS}

\section{the collaborative creation of power in multilingual schools} edited by Jim Cummins and Margaret Early

This book shows how identity texts have been used as a central focus for effective and inspirational pedagogy in multilingual school contexts that is engaging students around the world.

The term identity texts was first used by the Canada-wide Multiliteracies Project to describe a variety of creative work by students, including collaborative inquiry, literary narratives, dramatic and multimodal performances, led by classroom teachers. Jim Cummins and Margaret Early describe their nature, the ways in which they relate to broader orientations to pedagogy and consider two pedagogical frameworks within which they have been integrated.

This is followed by brief case studies of identity text construction by educators and students in schools in parts of North America, in Burkina Faso and Rwanda in Africa, and in Ireland. The identity texts produced held up a mirror to the students which reflected their identities back in a positive light. The closing chapters elaborate on their central role in bilingual instructional strategies and highlight future projects generated by brainstorming among the contributors to this volume.

June 2011, ISBN 978185856478 4, 192 pages, 244 x 170mm, £20.99 